\title{
Self-Concept, Self-Efficacy and Self Esteem as Predictors of Academic Performance in Mathematics among Junior Secondary School Students in Edo State
}

Margaret Ose Asika: Department of Curriculum and Instruction Faculty of Education, Ambrose Alli University, Ekpoma, Edo state, Nigeria.

\begin{abstract}
This study examined Self-Concept, Self-Efficacy, and Self-Esteem as Predictors of Academic Performance in Mathematics among Junior Secondary School Students in Edo State. The main purpose of the study is to determine the relationship between self-concept and academic performance in mathematics of Junior Secondary School students in Edo state. The study adopted the correlation research design. A sample of 3,639 was drawn from a population of 36,615 junior students in Edo state. The data generated for the study were obtained through a self designed questionnaire. Pearson Product Moment Correlation and Multiple Regression were used to analysed the data collected. The result obtained revealed the following: there was a positive relationship between self-concept and academic performance in mathematics among junior secondary school students, there was also a negative relationship between self-efficacy and academic performance in mathematics among junior secondary school students in Edo state. The study thus concluded that self-concept and self-efficacy are not only significantly related to academic performance, they significantly predict academic performance of students. It was therefore recommended that adequate and sufficient attention must be given to sustain the development of positive self-concept and self-efficacy of students in the school system, while deliberate efforts should be made to build up the self-esteem of the students and Teachers should be offered professional guidance by educational authorities on these self-constructs in students as an avenue to improve on students' academic performance.
\end{abstract}

Key words: Self-concept, Self-efficacy and self-esteem, Academic performance.

\section{Introduction}

Every educational process or program is expected to ensure that the students achieve a satisfactory outcome (Onyeizugbo, 2010) .Various variables (such as self-awareness, self-concept, self-efficacy, locus of control, self- esteem) are known to influence academic performance (Kaunda, 2010; Redmond, 2013; Zahra, 2010). These variables are therefore of great importance to educational researchers and other related disciplines. Many of the successes and/or failures that people experience in many areas of life are closely related to the ways that they have learned to view themselves and their relationships with others. For example, an individual performs better in any field if he believes in himself (self-concept), if he believes in his ability to perform a specific task (self-efficacy), and believes he is worthy of such task (self-esteem). This can possibly apply to school setting as well. It is likely that a student who has a high self-concept, self-efficacy and selfesteem will perform better in academics than his counterpart with low self-concept, low self-efficacy and low self-esteem. Since these three psychological variables have been known to influence performance, how much can academic performance depend on them? Although there are obviously other factors that can, and do affect the performance of students academically, many psychologists and educationists believe that these psychological constructs under study, if properly harnessed, will help to turn things around for students.

Studies

Volume 4, Issue 2, pp. 65-74

2021

2641-533x.v4i2.158

Funding: This study received no specific

financial support.

Received: 9 September 2021

Revised: 14 October 2021

Accepted: 11 November 2021

(C) 2021 by the authors; licensee Academic

Publishing Group 
Academic performance refers to how well or how badly a student is doing in the various subjects when his ability or knowledge in his course of study is tested. Academic performance ought to reveal how much a learner knows from the teacher or instructor. Nowadays however, academic performance is not what it should be as it has over the years taken downward turn which has resulted to falling/dwindling standard of academic performance in Nigeria. The problem of poor academic performance stems from the fact that many students have no self-confidence as well as self-beliefs. For example, the fear of mathematics is a learned behaviour of self-defeat. The poor performance in mathematics reveals the way that students react to it in their minds. Mathematics as a subject sends out such a negative feelings, which induces fear that no other subject does. Usually, this begins in early childhood due to negative or unpleasant experiences in the subject or its teacher.

The level of students' academic performance in mathematics in Edo State would be regarded as low. From observation, the level of participation in academic exercise, the passion that was supposed to be the hallmark of students' academic pursuit seems to have lost its heat. One of the reasons for this is the students' lack of the knowledge of self-concept, self-efficacy and self-esteem. A learner has to be involved with keen interest mind, body and soul for knowledge to take place. Hence, an individual can only perform well academically when his mind, his "self"- is wholly involved. Well-meaning educationists have expressed great concern on the falling or dwindling standard of education in Nigeria. This means academic performance, which should be the centre of educational process, is no longer what it should be. Among the numbers of reasons for the poor academic performance is lack of interest on the part of the students (Aluede, Okhiku, \& Udele, 2009).

Considering the fact that the educational sector is set up for the student for the sake of his future and the future of the nation, attention has to be drawn to his all-round personality development especially his "SELF" and his control. His self- concept, self- awareness, self- assessment, self- esteem, self- determination, selfefficacy, locus of control and so on have to be explored by him with the help of the parents, teachers, psychologists and guidance counselors. The student's perceptions and beliefs about himself help a great deal in seeing himself as one capable of thinking and not just a receptor to environmental force. Self-confidence naturally leads to self-realization, good performance and successful achievement. The importance of selfconcept, self-efficacy and self-esteem have to do with a special kind of mental attitude that helps the individual to believe in himself and release an inner power.

Self-concept is referred to as the image or perceptions that students hold about themselves; which include feelings, attitudes and knowledge about their abilities, skills and acceptance. The perception that every student has of himself between his self-concept and academic demands is important for learning outcomes. Selfconcept refers to the set of perceptions or reference points that the subject has about himself. This connotes the set of characteristics, attributes, qualities and deficiencies, capacities and limits, values and relationships that the subject knows to be descriptive of himself and which he perceives as data concerning his identity. It is a set of knowledge and attitude that we have about ourselves, the perception that the individual assigns to himself and characteristics or attributes that we use to describe ourselves. It is understood to be fundamentally a descriptive assessment (Sanchez \& Roda, 2007).

Self-efficacy is another construct which roughly corresponds with a person's belief in his own competence. It refers to the belief that one is capable of performing in a certain manner to attain a certain set of goals. In academic setting, self-efficacy refers to a student's belief that he can successfully enter into and complete a course of study. It is an individual's confidence in his ability to organize, execute, and regulate performance in order to solve a problem or accomplish a task at a designated level of skill and ability. It deals with the belief system of the student; that he is capable of entering into an academic task and accomplishes the course outcome (Redmond, 2013). It therefore refers to a person's conviction that he can successfully achieve at a designated level in a specific academic subject area.

Self-esteem is an opinion of what value or worth an individual places on himself (Beck, 2008). The importance of self-esteem lies in the fact that it concerns us ourselves; the way we are, the way we feel and the sense of our personal value or personal worth. A student with a high self-esteem views himself worthy enough to tackle any academic challenge while the one with low self-esteem is likely to have a self-defeating attitude thereby refraining from academic challenges. Thus, self-perception seems to have a lot of influence on every activity of an individual including academic performance in mathematics. The study and understanding of these self-constructs (that is, self- concept, self-efficacy and self-esteem) under discussion

bring this out in its clear terms. The way we view ourselves and feel about ourselves have a profound effect on

International Journal of Educational
Studies
Volume 4, Issue 2, pp. $65-74$
2021
DOI: $10.53935 / 2641-533 x . v 4 i 2.158$
Funding: This study received no specific
financial support.
Article History:
Received: 9 September 2021
Revised: 14 October 2021
Accepted: 11 November 2021
Published: 25 November 2021
() 2021 by the authors; licensee Academic
Publishing Group

| 66 
what we do and how we live our lives. Self-concept, self-efficacy and self-esteem are of vital importance in directing an individual's life towards a more productive and happy one. The premise of this study is that student's self-perception and beliefs in his self-concept, self-efficacy and self- esteem regarding academic competency could have important implication for improving students' performance (Aldridge \& Fraser, 2008).

In Nigeria, some principles have been put in place in the educational sector to enhance performance of students. However none is targeted towards given the learner a convincing value of his/herself, and researchers have not also been too concerned with the subject of self-value that triggers performance. Most of the studies known to the researcher on the relationship among self-concept, self-efficacy, self-esteem and academic performance that were reviewed were carried out in Europe, Asia and the Middle East. Few studies on these variables have been reported in Nigeria. This again is another important gap, which this study intends to fill. The study, therefore, examines the relationship between self-concept, self-efficacy, self-esteem and academic performance in mathematics among junior secondary school students in Edo State, Nigeria. The aim of this paper therefore is to examine determine the productiveness of self-concept, self-efficacy and selfesteem on academic performance in mathematics of Junior Secondary School students in Edo state.

\subsection{Research Question}

Do self-concept, self-efficacy, and self-esteem predict academic performance in mathematics among students in junior secondary schools in Edo State?

\subsection{Research Hypothesis}

Self-concept, self-efficacy, and self-esteem do not significantly predict academic performance in mathematics among junior secondary school students in Edo State.

\subsection{Theoretical Framework}

The major component of this study is developing a comprehension about how social cognitive factors influence academic performance through self-concept, self-efficacy and self- esteem of students. Given that internal thought processes and external behaviors/actions are influenced by human interactions (Bandura, 1982; Bandura, 1989; Bandura, 1991) self- image and self-perceptions during the adolescent period of development are largely affected by individuals' self- beliefs. The social cognitive theory revolves around the notion that learning correlates to the observation of a role model, and intentionally picking up a challenge. Bandura's action oriented, problem-solving approach appeals to those who want to make changes in their lives. Social cognitive theory is learning theories based on the ideas that people learn, emulate and aspire for greater heights by watching what others do, and that human thought processes are central to understanding personality. Its main concept is that an individual's actions and reactions in almost every situation is influenced by the actions which the individual has observed in others. The observations are remembered by the individual and help shape social behaviour and cognitive processes. The theory provides a framework for understanding, predicting and changing human behavior. It focuses on the application of cognitive learning principles to change problems that are associated with beliefs, thinking and feelings. The social cognitive theorists stress that people extensively control, or regulate their own behavior. According to Bandura (2005) social cognitive theory takes on an agentic perspective to change, development and adaptation. He described an agent as someone who intentionally influences one's functioning and life circumstances; in this view, people are self- organizing, proactive, self-regulating, and self-reflecting (Bandura, 2005).

According to the theory, behavioural and environmental information create the self- beliefs that, in turn, inform and alter subsequent behavior and environments. The theory emphasizes how cognitive, behavioural, personal, and environmental factors interact to determine motivation and behaviour (Crothers, Hughes, \& Morine, 2008). It is composed of four processes of goal realization: self-observation, self-evaluation, selfreaction and self- efficacy. These components are interrelated, each having an effect on motivation and goal attainment (Redmond, 2013). According to Locke and Latham (2002) as cited in Redmond (2013) although social cognitive theory covers many topics such as moral judgment and physiological arousal, research is primarily focused on self-efficacy, or the beliefs regarding one's capabilities of successfully completing tasks or goals. Bandura (1986) proposed a view of human functioning that emphasized the role of self-referent beliefs. In this socio-cognitive perspective, individuals are viewed as proactive and self-regulating rather than

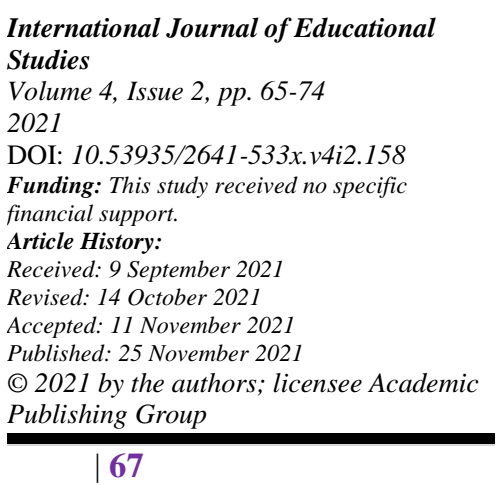


as reactive and controlled by biological or environmental forces. Bandura also emphasized that "people who regard themselves as highly efficacious act, think, and feel differently from those who perceive themselves as inefficacious. They produce their own future, rather than simply foretell it".

The social cognitive theory is relevant to this study in that all the variables believed that behaviour is not caused by a response to an outside stimulus, but instead, the behaviour is inspired by what a person wants most at any given time. It is believed that all living creation, control their behaviour to maximize their need satisfaction. The argument is that if students are not motivated to do their school work, it may be because they view school work as irrelevant to their basic human need (Wikipedia, 2010).

Regarding self-efficacy, Bandura (1995) as cited in Redmond (2013) explains that it refers to beliefs in one's capabilities to organize and execute the courses of action required to manage prospective situations. Self-efficacy is people's perception of their ability to do what is necessary to achieve desired goals (Bandura, 1997). More simply, self-efficacy is what an individual believes he or she can accomplish using his or her skills under certain circumstances (Snyder \& Lopez, 2007). Like social cognitive theory, the basic principle behind self-efficacy theory is that individuals are more likely to engage in activities for which they have high self-efficacy. Self-efficacy has been thought to be task specific version of self-esteem (Lunenburg, 2011). It is considered a situation- specific construct, content dependent and functions as a cognitive mediator of action (Bandura, 1982). Self-esteem is often seen as synonymous to self-concept and/or self-efficacy. Yet they differ from one another, but they can influence one another. The three constructs therefore utilize the important idea of social cognitive theory.

Since social cognitive development emphasizes the influence of interactions, development, and maturation of children and adolescents, it is applicable to the current study of academic self-concept, academic self-efficacy, self- esteem and academic performance. Again, the social cognitive theory thus becomes relevant to this study because it examines the importance of students' academic performance through the awareness of the use of self-constructs in their studies and all their school works. It provides an opportunity to students to decide whether to exert control and pursue a particular goal or not. It is related to self-concept, self-efficacy and self-esteem. Social cognitive theory is considered appropriate and therefore selected to guide this study.

\section{Methodology}

This study adopted the correlational research design. Correlational research design is useful when examining the degree of relationship or association between two or more variables (Colman, 2003). The method used in the study did not involve the manipulation of variables. The variables were observed as they existed and their relationship with the outcome variable was established.

The population of this study consisted of all JSS 3 students in public junior secondary schools in Edo State. The total population of students for the year 2018/2019 session stood at 36,615. This figure was made up of 18,290 boys (49.95\%) and 18,325 girls (50.05) in 298 Junior Secondary Schools in Edo State as obtained from Ministry of Basic Education, Benin City, 2013.

The sample size of this study was $10 \%$ of the entire JSS3 population of 36,615 . The target sample was therefore 3,639. The multi-stage sampling procedure involving stratified and simple random sampling technique was adopted to reach the target population. At the first stage purposive selection of Junior Secondary School in public secondary schools in Edo State was done. The population was stratified into three strata based on the three (3) senatorial districts of Edo State as follows: Edo Central, Edo North and Edo South Senatorial Districts. At the second stage, local government areas from each of the three (3) senatorial districts were sampled. This yielded nine (9) local government areas, representing fifty percent (50\%) of the total 18 local government areas in the state. At the third stage, actual schools and students to be used were balloted for. Four public junior secondary schools each were sampled from each of the nine local government areas that had earlier been sampled making 36 schools with a student's population of 3,639 constitute the sample of the study. Data were collected using a structured questionnaire and data collected were analysed using the Pearson Product Correlation Coefficient to answer research questions while the multiple regression analysis was applied to test the hypothesis. 


\section{Results and Discussion}

A Correlation Matrix of Self-Concept, Self-Efficacy, Self-Esteem and Academic Performance in Mathematics of Junior Secondary School Students in Edo State.

Table-1. A Correlation Matrix of Self-Concept, Self-Efficacy, Self-Esteem and Academic Performance in Mathematics of Junior Secondary School Students in Edo State

\begin{tabular}{lllll}
\hline & $\begin{array}{l}\text { Academic } \\
\text { Performance }\end{array}$ & $\begin{array}{l}\text { Self- } \\
\text { Concept }\end{array}$ & Self-efficacy & Self-esteem \\
\hline Academic Performance & 1 & $.032^{*}$ & $-.028^{*}$ & .023 \\
Self Concept Pearson Correlation & & 1 & $.258^{* *}$ & $.245^{* *}$ \\
Self-efficacy & & 1 & $.348^{* *}$ \\
Self Esteem Pearson Correlation & & & 1 \\
\hline *Correlation is significant at 0.05 level (2-tailed) & & &
\end{tabular}

$* *$ Correlation is significant at the 0.01 level (2-tailed) $\mathrm{N}=3,639$

The results in Table 1 showed that the coefficient of relationship between self-concept and academic performance in mathematics is $0.032(\mathrm{P}<.05)$, which indicates a positive and significant relationship. In the light of this, the null hypothesis of no significant relationship is hereby rejected. The data indicates that there is a significant relationship between self-concept, and academic performance in mathematics. The conclusion is that as self-concept increases, academic performance in mathematics also increases. Therefore, to a level of certainty, we should expect students with high level of self-concept to maintain a high level of academic performance in mathematics.

Multiple Regression Analysis of Relationship between Predictors (Self Concept, Self Esteem and Self Efficacy) and Academic Performance in Mathematics among Students of Junior Secondary Schools in Edo State.

Table-2. Multiple Regression Analysis of Relationship between Predictors (Self Concept, Self Esteem and Self Efficacy) and Academic Performance in Mathematics among Students of Junior Secondary Schools in Edo State.

\begin{tabular}{llllllllll}
\hline Variables & $\mathbf{N}$ & & Sd & $\mathbf{R}$ & $\mathbf{R}^{\mathbf{2}}$ & $\mathbf{F}$ & Sig. & $\mathbf{B}$ & $\mathbf{t}$ \\
\hline $\begin{array}{l}\text { Academic Performance } \\
\text { in Mathematics }\end{array}$ & 3639 & 48.52 & 15.35 & & & & & & \\
Self-Concept & & & & & & & & & \\
Self-Efficacy & 3639 & 38.75 & 8.74 & .157 & .013 & 3.934 & 0.05 & .065 & 2.140 \\
Self-Esteem & 3639 & 30.46 & 9.26 & & & & & -.079 & -2.665 \\
\hline
\end{tabular}

Table 2 presents the variables that were entered into the multiple regression equation. The Table shows the percentage of variability in the dependent variable (academic performance in mathematics). This is accounted for by all the independent variables (self efficacy, self esteem and self concept) together, which is $\mathrm{R} 2$ square $=0.013$. It also reveals an F-test of (3.934) at $\mathrm{p} .<.05$ level of significance. The result of the analysis showed that self-concept, self-efficacy and self-esteem combined contribute significantly (though the contribution is very minimal) to academic performance in mathematics among junior secondary school students in Edo State.

Also, Table 2 reveals Beta (weight), which was used to determine the relative contribution of a particular independent variable in the equation after controlling for the effects of all other independent variables. The result of the analysis showed self-efficacy with beta value, $b=-.079, t(-2.665)$; self concept $b=.065, t(2.140)$ and self-esteem, $\mathrm{b}=.054, \mathrm{t}(1.707)$ where $\mathrm{P}<0.05$ in all cases.

From the analysis therefore, self-concept, self-efficacy and self-esteem contributed $13 \%$ to the variance of academic performance in mathematics among junior secondary school students in Edo state. Self-concept was the best predictor followed by self-efficacy with negative connotation. Self-esteem however did not show predictive value to academic performance in mathematics. Therefore, the null hypothesis which states that self-concept, self- efficacy, and self-esteem do not significantly predict academic performance in mathematics among junior secondary school students in Edo state is rejected.

Studies

Volume 4, Issue 2, pp. 65-74

2021

Funding: This study received no specific

financial support.

Article History.

Received: 9 September 202I

Revised: 14 October 2021

Accepted: 11 November 2021

Published: 25 November 2021

(C) 2021 by the authors; licensee Academic

Publishing Group 


\section{Summary of Major Findings}

The major findings of the study are summarized below:

1. There is a significant positive relationship between self-concept and academic performance in mathematics among Junior Secondary School students in Edo State.

2. There is a significant negative relationship between self-efficacy and academic performance in mathematics among Junior Secondary School students in Edo State.

There is a positive but non-significant relationship between self-esteem and academic performance in mathematics among Junior Secondary School students in Edo State.

Self-concept, self-efficacy and self-esteem jointly significantly predict academic performance in mathematics among Junior Secondary School students in Edo State. However, taking individually, only selfconcept and self- efficacy predict academic performance. Self-esteem does not.

\section{Discussion of Findings}

Findings of this study are discussed under the following sub-headings:

\subsection{Relationship between Self-Concept and Academic Performance in Mathematics \\ 5.2. Relationship between Self-Efficacy and Academic Performance in Mathematics \\ 5.3. Relationship between Self-Esteem and Academic Performance in Mathematics \\ 5.4. Predictiveness of Self-Constructs to Academic}

Relationship between Self-Concept and Academic Performance in Mathematics: This study has shown that there is a significant positive relationship between self-concept and academic performance in mathematics among junior secondary school students in Edo State. The reason for this is not far-fetched. An individual's behavior is influenced by what the individual thinks about himself. If an individual has a positive view about himself, such individual will likely have a positive attitude towards his academic pursuit. This becomes more relevant when the individual feels that he is able to excel in some subjects where he feels he has great aptitude. In this case, such self-ability enables or prompts him to develop more interest in the subjects, despite the acclaimed difficulties (Zahra, 2010). This finding is in line with Dambudzo (2005); Zahar (2014) and Afuwape (2011) who earlier found, in their independent studies, a significant relationship between self-concept and students academic performance.

Empirical evidence abounds that self-concept beliefs is related to and also influences academic performance. Self-concept also works with and influences other self-beliefs that have predictive influence on academic performance. This means that self-concept working together with other self-beliefs such as selfefficacy and self- esteem etc. positively predicts academic performance. Researchers have reported relationships between self-concept and academic performance in mathematics. The relationships as it is with other self-concepts can run from a strong negative correlation to a nearly perfect positive correlation, Hansford and Hattie (1982). Yet a lot of the studies reported from moderate to a weak correlation.

In the same vein, many researchers have found a significant positive relationship between self-concept and students academic performance in mathematics especially on the premise that self-concept controls an adolescent's behaviour, just as it plays dominant role in their behavour modification (Colman, 2003; Hassan, 2010; Hattie, 1992; Illeris, 2004; Iqbal, 2003; Okoko, 2012). To these researchers, any academic outcome depends primarily on what one thinks and feels about oneself. This serves as a morale booster to learn (Colman, Pulford, Omtzigt, \& al-Nowaihi, 2010) and a motivational impetus for positive achievement (Illeris, 2004).

Many students are generally believed to be scared of mathematics and science subjects like Physics and Chemistry. This pseudo notion allegedly follows students to secondary schools from primary schools. Even at the primary school level, many pupils are acclaimed to develop phobia for mathematics. This phobia seems to culminate into abysmal low performance in mathematics (Hattie, 1992). Mathematics may not be difficult but the "defeatist perception" of the students makes them fail, and this is where the concept of self-concept becomes important in this study. It stands to reason, therefore, that if a student believes that a subject is difficult, it becomes difficult and if it is perceived easy, it becomes easy. This thought and feelings (selfconcept) directly influence students' performance favorably or adversely.

The study also indicates that the higher the self-concept, the higher the academic performance. This findings is in tandem with the earlier findings of Zimmerman (2000); Shafique (2002); Von Stumm, Hell, and

International Journal of Educational
Studies
Volume 4, Issue 2, pp. $65-74$
2021
DOI: $10.53935 / 2641-533 x . v 4 i 2.158$
Funding: This study received no specific
financial support.
Article History:
Received: 9 September 2021
Revised: 14 October 2021
Accepted: 11 November 2021
Published: 25 November 2021
( 2021 by the authors; licensee Academic
Publishing Group

$\mid 70$ 
Chamorro-Premuzic (2011) and Dramanu and Balarabe (2013). Self-concept may be developed from peers or the family where children are encouraged to face life with courage (education inclusive). Peer friends who believe in working hard at school invariably make the group members hardworking Yaro (2010). Such friends may form study group and display their knowledge in class at the slightest opportunity. Moreso, display of knowledge has a correlation with academic performance (Shafique, 2000). Answering questions in class, especially in subjects deemed difficult, allegedly acquire high level of self; believing that they can excel in each subjects. In the case of science subjects like physics and chemistry and biology (and basically mathematics) that are presumed difficult, many students who developed interest in the subjects and believed that they can excel in the subjects are today great scientists (Dramanu \& Balarabe, 2013; Illeris, 2004). Family background may also enhance self-concept. This is more pronounced in families where parents are educated and encourage their children and wards to study a particular course. This could be the reason why we find children of parents who are doctors, pharmacists, nurses, medical laboratory officers, and even engineers excelling in science subjects (Yaro, 2010).

It was found that a significant positive relationship exists between self-concept and academic performance among junior secondary school students in Edo state. This therefore implies that self-concept is a predictor of academic performance. The reason for this might be due to the fact that when a child (or anyone for that matter) has a positive self-concept, he/she attacks any challenge that may come across the individual's way. As a result, self- concept plays a major role in student's academic performance. The conclusion is that as self-concept increases academic performance also increases. Therefore, to a level of certainty, we should expect students with high level of self-concept to maintain a high level of academic performance.

Relationship between Self-Efficacy and Academic Performance in Mathematics: This study found that self efficacy has a significant negative relationship with academic performance in mathematics among junior secondary school students in Edo state. This may be due to anxiety or fear of failing mathematics at that level. This is because previous experiences of success and failure may have come into play since self-efficacy beliefs are always specific to particular situations. This is in line with the findings of Bandura (1997); Pajares and Schunk (2010) who in their various studies agree that self-efficacy beliefs are sensitive to particular tasks or activities.

Again, the relationship between self-efficacy and academic performance in mathematics in this study being negative may be due to over-working/fatigue, anxiety, over-confidence and enthusiasm. Self-efficacy beliefs are known to be easily affected by high emotional arousal. This equally affects performance either positively or negatively (Michael, 2003; Smith, 1987).

The result of this study, which indicated a negative relationship, could mean a strong negative belief (selfefficacy) about mathematics. Having a negative belief that mathematics is difficult and a subject one cannot pass especially at young adolescent's stage may result to poor performance. This is in line with Pajares and Miller (1995); Zimmerman (2000); who studied the relationship between self-efficacy and student's anxiety reactions regarding mathematics and found a negative correlation between them.

A strong sense of efficacy enhances human accomplishment and well-being in countless ways. Confident individuals approach difficult tasks as challenges to be mastered rather than as threats to be avoided.

The teacher's self-efficacy beliefs are related to and also influence the students' beliefs and performance. Self- efficacious teachers create atmosphere in and around the classroom so that rigorous academic activities and intellectual challenges are made to look interestingly simpler. With the appropriate and necessary emotional support and encouragement, students will meet with challenges and perform excellently well in academics. Since teacher's own self-beliefs can have either a positive or negative influence (a lifelong security risk) on that of the students, they (teachers) have to seriously deal with their own belief system if their students would come out well nurtured and confidence. The conclusion is that as self-efficacy increases, academic performance decreases to some extent and / or vice visa. To some level of certainty we should therefore expect students with high self-efficacy to be over- confident thereby performing poorly in mathematics.

Relationship between Self-Esteem and Academic Performance in Mathematics: From the findings of this study there is a weak positive relationship between self-esteem and academic performance in mathematics among junior secondary school students in Edo state. The result is not unexpected. It only tells that their selfesteem, self- worthiness when it comes to mathematics is low. Many just do not believe, that they are worthy

International Journal of Educational
Studies
Volume 4, Issue 2, pp. $65-74$
2021
DOI: 10.53935/2641-533x.v4i2.158
Funding: This study received no specific
financial support.
Article History:
Received: 9 September 2021
Revised: 14 October 2021
Accepted: 11 November 2021
Published: 25 November 2021
@ 2021 by the authors; licensee Academic
Publishing Group

|71 
of a high mark in mathematics. Many students therefore display low self-esteem as a result of feelings of inadequacy over inability to solve mathematical problems perhaps right from the primary schools. This aligns with Lawrence (2000); who found in his study that majority of students are likely to have low self-esteem as a result of feeling inadequate over not being good in some subjects and in addition have low self-esteem as a result of other experiences probably beginning in childhood. The result also in line with the findings of Pullmann and Allik (2008) who found a low (not high) self- esteem but a significant predictor of academic performance among students. Several other researchers (Hossaini, 2002; Marsh \& O'Mara, 2008; Naderi, Abdullah, Aizan, Sharir, \& Kumar, 2009) found various moderate relationships between self-esteem and students' academic performance. Again at the students' age and level of education, and in a society where children are mostly not aware of the self-worth concept, low self-esteem may not mean poor performance especially when it comes to a subject like mathematics. Since self-esteem refers to the overall evaluation of oneself (ones worthiness) in either positive or negative way, true judgment of self-worthiness may be difficult at this stage. It might not be easy for a junior student to judge their feelings of self-competence especially in mathematics. Pajares and Schunk (2001) stressed that an obsession with ones sense of self is responsible for an alarming increase in depression and other mental difficulties. As this may not mean zero relationship between self-esteem and academic performance, it is in line with Malbi and Reasoner (2008) who found that low general self-esteem does not necessary signal poor performance. The findings revealed a limited correlation (0.026) between self-esteem and academic performance in mathematics. This means whether high or low, self-esteem is a significant predictor of academic performance (Pullmann \& Allik, 2008).

Many other researchers found a no significant relationship between self-esteem and academic performance. For instance, Naderi et al. (2009) in their study titled self-esteem, gender and academic achievement of undergraduate students found no significant relationship between self-esteem and academic performance. However, this result contradict the popular findings by researchers Hamachek (1995); Okoko (2012); Afari, Ward, and Khine (2012) etc. who found positive and significant relationship between selfesteem and academic performance in their various studies. Today, researchers see self-esteem as a major factor in learning. They consistently report a positive correlation between how much worth students place on themselves and their academic performance. If the student is confident or has high self-esteem he/she performs well in academics, but where the students do not have self-confidence they perform less.

Teachers at this level have a way of building in their students' self-beliefs that can either have beneficial or destructive influence to them. If the teacher's self-esteem is low either from his personal life or not which can be noticed from appearance, dressing, speech or conversation either with students or fellow teachers, some students might hate the subject and their self-esteem might be in danger. Consistent lower marks from a particular subject may make a student develop low self-esteem on a particular subject. As in this study, mathematics subject may be the reason why their true self-esteem cannot be detected. Good results/marks have a way of building up one's sense of self-worthiness and competence. Some researchers who investigated the relationship between self-esteem and academic performance found that high self-esteem facilitates academic performance yet only a limited correlation was revealed between self-esteem and academic performance (Pullmann \& Allik, 2008). The conclusion is that as self-esteem decreases, academic performance in mathematics also decreases to some extent. To some level of certainty, therefore, we should expect students with lower self-esteem to maintain a corresponding lower level of academic performance in mathematics.

\section{Conclusion}

This study finds out that self-concept and self-efficacy are not only significantly related to academic performance, they significantly predict academic performance of students. The result indicates that selfconcept proved to have a stronger relationship with academic performance in mathematics followed by selfefficacy. Self- esteem though positively related to academic performance, does not significantly predict academic performance in mathematics.

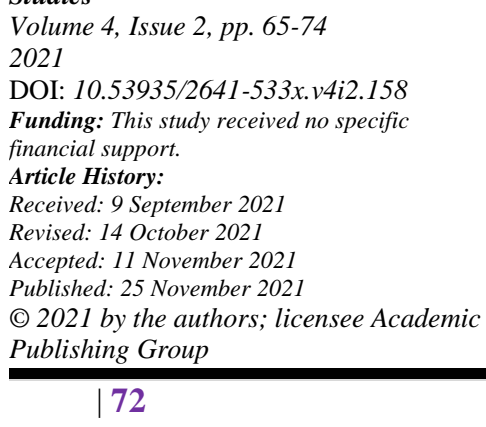

\section{Recommendations}

Based on the findings of this study, the following recommendations were made:

i. Adequate and sufficient attention must be given to sustain the development of positive self-concept and self- efficacy of students in the school system, while deliberate efforts should be made to build up 
the self- esteem of the students.

ii. Teachers should be offered professional guidance by educational authorities on these self-constructs in students as an avenue to improve on students' academic performance.

iii. Teaching or helping of students to develop positive self-construct especially the academic type, is a sensitive issue. It should not be left alone for only classroom teachers. Other professionals in schools must be involved. It should be the concern of the entire educational team.

iv The government should employ psychologists and guidance counselors to help train children in selfbeliefs right from the primary schools level.

\section{References}

Afari, E., Ward, G., \& Khine, M. S. (2012). Global self-esteem and self-efficacy correlates: Relation of academic achievement and self-esteem among emirati students. International Education Studies, 5(2), 49-57.

Afuwape, M. O. (2011). Students self-concept and their achievement in basic science. African research review. An International Multidisciplinary Journal Ethiopia, 5(4), 51-57.

Aldridge, J. M., \& Fraser, B. J. (2008). Outcomes-focused learning environments: Determinants and effects. Rotterdam, The Netherlands: Sense Publishers.

Aluede, R., Okhiku, I., \& Udele, J. (2009). Falling standard of education in Nigeria: A critique. Journal of Teacher Education and Teaching, $9(1$ and 2), 16-20.

Bandura, A. (1982). Self-efficacy mechanism in human agency. American Psychologist, 37(2), 122-147.

Bandura, A. (1989). Self-regulation of motivation and action through internal standard and goal systems. Goal concept in personality and social psychology. L. A. Pervin (Ed) (pp. 19-85). Hillsdah, NJ: Erlbaum.

Bandura, A. (1991). Social cognitive theory of self-regulation. Organizational Behavior and Human Decision Processes, 50(2), 248287.

Bandura, A. (2005). The evolution of social cognitive theory. Great minds in management. K. G. Smith and M. A. Hitt (Eds.). Oxford. 1: Oxford University Press.

Bandura, A. (1986). Social foundations of thought and action: A social cognitive theory. Englewood Cliffs, NJ: Prentice Hall.

Bandura, A. (1995). Self-efficacy: The exercise of control. New York: Freeman.

Bandura, A. (1997). Self-efficacy: The exercise of control. New York: Freeman.

Beck, M. (2008). If at first you don't succeed, you are in excellent company. The Wall Street Journal, 3(1), 180-194.

Colman, A. M. (2003). A dictionary of psychology. Great Clarendon Street, Oxford ox2 6DP: Oxford University Press.

Colman, A. M., Pulford, B. D., Omtzigt, D., \& al-Nowaihi, A. (2010). Learning to cooperate without awareness in multiplayer minimal social situations. Cognitive Psychology, 61(3), 201-227.

Crothers, L. M., Hughes, T. L., \& Morine, K. A. (2008). Self-efficacy and social cognitive theory. Retrieved from http://wikispaces.psu.edu/display/psych484/sum2013.

Dambudzo, I. I. (2005). The relationship between learner self-concept and achievement in secondary schools in Zimbabwe. Unpublished Ph.D Thesis. University of South Africa: Zimbabwe.

Dramanu, B. Y., \& Balarabe, M. (2013). Relationship between academic self-concept and academic performance in junior high school students in Ghana. European Scientifit Journal, 9(3), 218-246.

Hamachek, D. (1995). Self-concept and school achievement: Interaction dynamics and a tool for assessing the self-concept component. Journal of Counseling \& Development, 73(4), 419-425.

Hansford, B. C., \& Hattie, J. A. (1982). The relationship between self and achievement/performance measures. Review of Educational Research, 52(1), 123-142.

Hassan, S. (2010). Developing staff for the implementation of problem-based learning: Experiences from Botswana. South African Journal of Higher Education, 24(1), 84-97.

Hattie, J. A. (1992). Enhancing self-concept. In John hattie self-concept. Hillsdale, NJ: Erlbaum.

Hossaini, S. M. (2002). Forecasting between Self-esteem, parenting and gender among pre-university of students in Shiraz. Shiraz, Iran: Shiraz university of Shiraz.

Illeris, K. (2004). Transformative learning in the perspective of a comprehensive learning theory. Journal of Transformative Education, 2(2), 79-89.

Iqbal, N. (2003). Gender specific activities and its relationship with self-concept. New York: Omberk Inc.

Kaunda, A. (2010). Cultivating Kaunda's plan for self-sufficiency: Is urban agriculture finally beginning to receive support in Zambia?

Lawrence, S. J. (2000). Self-esteem in young adolescents: Emotional and cognitive reactions to success and failure: Fordham University.

Locke, E. A., \& Latham, G. P. (2002). Building a practically useful theory of goal setting and task motivation: A. 35-years. Odyssey American Psychologist, 57(9), 05-717.Available at: https://doi.org/10.1037/0003-066x.57.9.705.

International Journal of Educational Studies

Volume 4, Issue 2, pp. 65-74

2021

DOI: $10.53935 / 2641-533 x . v 4 i 2.158$

Funding: This study received no specific

financial support.

Article History:

Received: 9 September 2021

Revised: 14 October 202

Accepted: 11 November 2021

Accepted: 11 November 2021

(c) 2021 by the authors; licensee Academic

Publishing Group
Lunenburg, F. C. (2011). Self-efficacy in the workplace: Implications for motivation and performance. International Journal of Management, Business, and Administration, 14(1), 1-6.

Malbi, R. S., \& Reasoner, R. W. (2008). Self-esteem, enhancing. Paper presented at the Self-Esteem Seminar. Sdn. Bhd.: Kuala Lumpur.

Marsh, H. W., \& O'Mara, A. (2008). Reciprocal effects between academic self-concept, self-esteem, achievement, and attainment over seven adolescent years: Unidimensional and multidimensional perspectives of self-concept. Personality and Social Psychology Bulletin, 34(4), 542-552.

Michael, P. W. (2003). Psychology: The science of mind and behavior (2nd ed.) 
Naderi, H., Abdullah, R., Aizan, H. T., Sharir, J., \& Kumar, V. (2009). Relationship between creativity and academic achievement: A study of gender differences. Journal of American Science, 6(1), 181-190.

Okoko, W. O. (2012). Self-esteem and academic performance of students in public secondary schools in Ndhiwa District Kenya. Unpublished Research Project of University of Nairobi.

Onyeizugbo, E. U. (2010). Self-efficacy and test anxiety as correlates of academic performance. Nsukka: Department of Psychology, University of Nigeria.

Pajares, F., \& Schunk, D. H. (2010). The development of academic self-efficacy. Retrieved from https://www.uky.edu eushe2/pajares/schunkpajares2001.PDF.

Pajares, F., \& Miller, M. D. (1995). Mathematics self-efficacy and mathematics outcomes: The need for specificity of assessment Journal of Counseling Psychology, 42(2), 190-198.Available at: https://doi.org/101037.0022-0167.42.2.190.

Pajares, F., \& Schunk, D. H. (2001). Self-beliefs and school success: Self-efficacy, self-concept and school achievement. London: Abex Publishing.

Pullmann, H., \& Allik, J. (2008). Relations of academic and general self-esteem to school achievement. Personality and Individual Differences, 45(6), 559-564.

Redmond, B. F. (2013). Self-efficacy and social cognitive theories. PSYCH 484: Work attitudes and lob motivation- co. Retrieved from https://wikispaces.psu.edu/display/PSYCH484.

Sanchez, F. J. P., \& Roda, M. D. S. (2007). Relationship between self-concept and academic achievement in primary schools Almeria, Spain: Roda Press.

Shafique, A. (2002). Relationship between academic self-concept and academic achievement among school children. Islamabad., Pakistan: National Institute of Psychology, Quaid-e-Azam University.

Shafique, A. (2000). Relationship between academic: Self-concept and academic achievement among school children. Pakistan: National Institute of Psychology Quad-e-Azan University Islamabad.

Smith, R. H. (1987). Social comparison choice during ability evaluation: The effect of comparison publicity performance feedback and self esteem: University of North Caroline at Chapel Hill.

Snyder, C. R., \& Lopez, S. J. (2007). Positive psychology: The scientific and practical explorations of human strengths: Sage Publications, Inc.

Von Stumm, S., Hell, B., \& Chamorro-Premuzic, T. (2011). The hungry mind: Intellectual curiosity is the third pillar of academic performance. Perspectives on Psychological Science, 6(6), 574-588.

Wikipedia. (2010). Self-esteem wikipedia, the free encyclopedia.

Yaro, J. A. (2010). Customary tenure systems under siege: Contemporary access to land in Northern Ghana. Geo Journal, 75(2), 199214.

Zahar, A. (2014). Relationship between mental health and physical self-concept among the female body building coaches in Tehran clubs Safadasht Branch Islamic Azad University.

Zahra, A. T. (2010). Relationship of academic, physical and social self-concepts of students with their academic achievement. Contemporary Issues in Education Research, 3(3), 73-78.Available at: https://doi.org/10.19030/cier.v3i3.190.

Zimmerman, B. J. (2000). Self-efficacy: An essential motive to learn. Contemporary Educational Psychology, 25(1), 82-91.

International Journal of Educational Studies

Volume 4, Issue 2, pp. 65-74

Volume

DOI: $10.53935 / 2641-533 x . v 4 i 2.158$

Funding: This study received no specific

financial support.

Article History:

Received: 9 September 2021

Revised: 14 October 2021

Accepted: 11 November 2021

Accepted: 11 November 2021

(c) 2021 by the authors; licensee Academic

Publishing Group 